\title{
IMPLEMENTASI TOTAL QUALITY MANAGEMENT PENDIDIKAN MELALUI USWAH HASANAH PADA TK-IT UMAR BIN KHATHAB KUDUS
}

\author{
Himmatul Ulyani, M Pd \\ Yayasan asy'ariyah Jepara \\ himmaulyani@gmail.com
}

\begin{abstract}
Abstrak
Penelitian ini dilatarbelakangi oleh banyaknya para wali anak didik yang menjadi pekerja dari pagi hari hingga siang menjelang sore hari, dan kemajuan zaman yang sangat pesat dengan globalisasi mereka ingin tetap terpenuhinya hak-hak anak mendapatkan pendidikan umum dan keagamaan dalam satu kelola lembaga yang berkualitas. Hasil penelitian ini sebagai berikut: (1) Konsep penerapan TQM di TKIT Umar Bin Khathab Kudus analisis internal dan eksternal, melakukan evaluasi program sekolah yang dilakukan setiap awal dan akhir semester, dengan berprinsip; partisipasi aktif dari semua pihak, Berorientasi pada mutu berdasarkan kepuasan pengguna, dinamika manajemen top down dan bottom up, menanamkan budaya "team work" dengan baik, menanamkan budaya problem solving melalui konsep PDCA (Plan-Do-Check-Action), sertaperbaikan berkelanjutan. (2) Implementasi $T Q M$ pendidikan dalam pengembangan kurikulum dengan pendekatan uswah hasanah di TKIT Umar bin Khathab Kudus; fokus pada pelanggan, keterlibatan total, pengukuran, komitmen, perbaikan berkelanjutan, (3) Peranan TQM pendidikan dalam meningkatkan kinerja organisasi dengan pendekatan uswah hasanah di TKIT Umar bin Khathab Kudus; obsesi terhadap mutu, pendekatan ilmiah, kerjasama tim (teamwork), pendidikan dan pelatihan, kebebasan yang terkendali, kesatuan tujuan.
\end{abstract}

Kata Kunci : Total Quality Management; Uswah Hasanah; TKIT

\begin{abstract}
This research is motivated by the number of guardians of students who become workers from the morning until noon in the afternoon, and the progress of the times is very rapid with globalization they want the fulfillment of children's rights to get general and religious education in a quality management institution. The results of this study are as follows: (1) The concept of applying TQM at TKIT Umar Bin Khathab Kudus, internal and external analysis, evaluating school programs conducted at the beginning and end of the semester, principally; active participation of all parties, quality oriented based on user satisfaction, top down and bottom up management dynamics, instilling a culture of "team work" well, instilling a culture of problem solving through the concept of PDCA (Plan-DoCheck-Action), and continuous improvement. (2) Implementation of TQM education in the development of curricula with the approach of hasanah at TKIT Umar bin Khathab Kudus; focus on customers, total involvement, measurement, commitment, continuous improvement, (3) the role of TQM education in improving organizational performance with the approach of hasanah prayer at TKIT Umar bin Khathab Kudus; obsession with quality, scientific approach, teamwork, education and training, controlled freedom, unity of purpose.
\end{abstract}

Keywords: Total Quality Management; Uswah Hasanah; TKIT 


\section{A. Pendahuluan}

Berdasarkan Undang-Undang Sistem Pendidikan Nasional Nomor 20 tahun 2003 menyatakan bahwa pendidikan adalah usaha sadar dan terencana untuk mewujudkan suasana belajar dan proses pembelajaran agar anak didik secara aktif mengembangkan potensi dirinya untuk memiliki kekuatan spiritual keagamaan, pengendalian diri, kepribadian, kecerdasan, akhlak mulia, serta keterampilan yang diperlukan dirinya, masyarakat, bangsa dan negara (UndangUndang Republik Indonesia Nomor 20 tahun 2003 tentang Sistem Pendidikan Nasional, Bab 1, Pasal 1). Interaksi yang terjadi antara individu dengan lingkungan sekitarnya, membuktikan bahwa telah terjadi adanya proses belajar mengajar.

Peningkatan kualitas pendidikan itu sendiri sebuah keniscayaan yang harus dilakukan di dunia pendidikan. Suatu proses yang terintegrasi dengan proses peningkatan kualitas sumber daya manusia itu sendiri. Undang-undang No. 20 tahun 2003 tentang sistem pendidikan nasional pada bab IV pasal II ayat 2 menyatakan bahwa "pemerintah dan pemerintah daerah wajib memberikan layanan dan kemudahan, serta menjamin terselenggaranya pendidikan yang bermutu bagi setiap warga negara tanpa diskriminasi” (Undang-undang No. 20 tahun 2003 tentang sistem pendidikan nasional pada bab IV pasal II ayat 2, diakses pada tanggal 27 Oktober 2017).

Berdasarkan situasi zaman saat ini ditengah-tengah kehidupan global yang sangat kompetitif manusia akan merasasurviveketika ia dapat merubah tantangan menjadi peluang, dan dapat mengisi peluang tersebut secara produktif. Sementara itu faktor kepribadian atau moralitas yang baik akan menjadi salah satu daya tarik dalam berkomunikasi dengan sesama manusia. Masa depan membutuhkan manusia-manusia yang kreatif, inovatif, dinamis, terbuka, bermoral baik, mandiri atau penuh percaya diri, menghargai waktu, mampu berkomunikasi dan memanfaatkan peluang serta menjadikan orang lain sebagai mitra (Abudin Nata, 2007 : 170).

Pendidikan di abad ini menuntut adanya manajemen pendidikan yang modern, professional serta bernuansa pendidikan. Lembaga-lembaga pendidikan diharapkan mampu mewujudkan peranannya secara efektif dengan keunggulan dalam kepemimpinan, proses belajar mengajar, pengembangan 


\section{Himmatul}

staf, kurikulum, tujuan dan harapan, iklim sekolah, penilaian diri, komunikasi, dan keterlibatan orang tua atau masyarakat. Serta yang tidak kalah pentingnya adalah sosok kinerja kepala sekolah dan guru yang ditandai dengan adanya keunggulan dan profesionalisme dalam sikap nasionalisme dan jiwa juang, keimanan serta ketakwaan, penguasaan Iptek, etos kerja dan disiplin, kerja sama dan belajar dengan berbagai disiplin, wawasan masa depan, kepastian karier, dan kesejahteraan lahir batin (Kunandar, 2007 : 12). Dalam konteks tujuan pendidikan, manusia yang unggul adalah manusia yang cerdas dan berwatak baik dalam bidang kecerdasan intelektual, sosio-emosional, maupun spiritual. Manusia seperti inilah yang diharapkan akan dapat berguna dalam dunia yang sedang berubah, dan mampu mencapai keunggulan dalam era persaingan global (Abdul Aziz Wahab, 2011 : 275). Kemajuan bidang ekonomi suatu negara pada gilirannya juga sangat berpengaruh terhadap perkembangan dan proses pendidikan.

Setiap anak memiliki tingkat pengetahuan dan keterampilan yang berbeda-beda, hal itu dapat diketahui sejak usia dini anak mulai dapat berinteraksi dengan lingkungan sekitar. Hasil dari interaksi tersebut akan menimbulkan perilaku yang berbeda dari sebelumnya. Hal ini dijelaskan dalam Undang-undang Nomor 20 Tahun 2003 tentang Sistem Pendidikan Nasional Pasal 1 ayat 14 yang menyatakan bahwa Pendidikan Anak Usia Dini (PAUD) adalah suatu upaya pembinaan yang ditujukan kepada anak sejak lahir sampai dengan usia enam tahun yang dilakukan melalui pemberian rangsangan pendidikan untuk membantu pertumbuhan serta perkembangan jasmani dan rohani agar anak memiliki kesiapan dalam memasuki pendidikan lebih lanjut (Undang-Undang Republik Indonesia Nomor 20 tahun 2003, Pasal 1 ayat 14, hlm. 2).Upaya penyelenggaraan suatu taraf pendidikan bagi masa usia pra sekolah merupakan peran penting bagi tumbuh kembang anak untuk tahap usia selanjutnya. Upaya ini salah satunya yakni penyelenggaraan pendidikan anak usia dini yang menitikberatkan pada peletakan dasar ke beberapa arah diantaranya yakni Pertumbuhan dan perkembangan fisik, kecerdasan,sosioemosional yang disesuaikan dengan keunikan dan tahap-tahap perkembangan yang dilalui oleh anak usia dini (Maimunah Hasan, 2012 : 1516). Masa anak usia dini merupakan masa keemasan (the golden age), dan 


\section{Himmatul}

sekaligus periode yang sangat kritis dalam tahap perkembangan manusia. Sampai usia empat tahun tingkat kapabilitas kecerdasan anak telah mencapai 50\% (Direktorat Pendidikan Anak Usia Dini, 2010 : 1).

Lembaga pendidikan bisa berhasil dengan baik pada era globalisasi sekarang ini dengan cara pertama, pada komitmen strategi para pengelola lembaga pendidikan dari top manajer yaitu kepala sekolah sampai pegawai terendah untuk membangun kepuasan serta citra nilai yang baik terhadap konsumen, apapun jenis lembaga atau perusahaannya (produksi maupun jasa). Kedua, perusahaan atau lembaga kependidikan yang berhasil adalah yang mampu menyesuaikan diri terhadap perubahan lingkungan secara terus menerus. Oleh karena itu konsep strategi yang komprehensif sebaiknya memandang sasaran, kebijakan, dan terencana tindakan sebagai suatu kesatuan yang tidak terpisahkan dan pelaksanaannya bersifat dinamis. Manajemen di sini merupakan seluruh unsur perencana dalam pengambilan keputusan strategis lembaga pendidikan, yang terdiri dari kepala madrasah atau sekolah, dewan guru, komite sekolah atau madrasah, pengawas, konsultan pendidikan, sebagai perencana strategis. Karena itu, kemampuan kepala sekolah dan personal sekolah lainnya mengimplementasikan suatu strategi dalam manajemen sekolah merupakan hal yang sangat penting dalam kaitannya dengan skill.

Perkembangan masyarakat yang semakin kompetitif menuntut setiap orang untuk berkompetisi secara sehat. Demikian halnya dengan sebuah lembaga, termasuk lembaga pendidikan. Kompetisi untuk merebut pasar menuntut setiap lembaga untuk mengedepankan kualitas dalam proses manajerialnya dan pembelajarannya. Dalam kaitannya dengan persoalan kualitas ini, TQM dapat digunakan untuk menggambarkan dua gagasan yang berbeda tetapi saling berkaitan.

Kehidupan umat manusia tidak terlepas dari adanya kecenderungan untukmeniru idolanya. Kecenderungan yang baik adalah sifat bawaan sejak kecil (kanak-kanak),yang akhirnya dibawa sampai usia dewasa. Itulah yang dikatakan dalampandangan Islam "uswatun hasanah". Hal ini memerlukan aplikasi di segala aspekkehidupan umat manusia.Konsep pendidikan kini berupaya merekontruksi kembali pentingnyapendidikan moral atau pendidikan akhlak. Sehingga sangat diutamakan untuk tetap terpenuhinya hak-hak anak 


\section{Himmatul}

mendapatkan pendidikan dengan mendapatkan pendidikan umum dan keagamaan dalam satu kelola lembaga. Maka sangat perlu pengembangan kurikulum yang berorientasi kepada kebutuhan masyarakat (pelanggan) yang sesuai situasi dan kondisi saat ini adalah sangat perlu suatu model gagasan pengembangan kurikulum yang berorientasi pada kualitas (mutu), (Wawancara pada Arie Widiana Ristiani, selaku Kepala TKIT Umar Bin Khathab, pada Selasa, 6 Februari 2018, pukul 09.10-09.45 WIB di Kantor TKIT Umar Bin Khathab Kudus (Jember).

\section{B. Pembahasan}

1. Analisis Tentang Konsep Total Quality Management Pendidikan di TKIT Umar Bin Khathab Kudus

Manajemen mutu terpadu (Total Quality Management) merupakan suatu penerapan metode dan sumber daya manusia untuk memperbaiki dalam penyediaan bahan baku maupun pelayanan bagi organisasi, semua proses dalam organisasi pada tingkat tertentu di mana kebutuhan pelanggan terpenuhi sekarang dan di masa mendatang. TQM lebih merupakan sikap dan perilaku berdasarkan kepuasan atas pekerjaannya dan kerja tim atau kelompoknya. TQM merupakan budaya yang harus dibangun, dipertahankan, dan ditingkatkan oleh seluruh anggota organisasi atau perusahaan bila organisasi atau perusahaan tersebut berorientasi pada mutu dan menjadikan mutu sebagai way of life.

$T Q M$ merupakan konsep yang jauh lebih luas, yang tidak hanya menekan pada aspek hasil tetapi juga kualitas manusia dan kualitas prosesnya. Bahkan menegaskan bahwa kualitas bukan hanya mencakup produk dan jasa, tetapi juga meliputi proses, lingkungan, dan manusia. Penerapan TQM yang terpenting adalah keterlibatan secara menyeluruh setiap orang dalam organisasi atau perusahaan tersebut untuk mengubah budaya (culture) yang lama menjadi budaya baru. Perubahan tersebut antara lain;

Merubah dari kerahasiaan atau sesuatu yang bersifat selentingan menjadi komunikasi terbuka antar seluruh anggota organisasi. Sebagaimana yang diperoleh data hasil wawancara peneliti kepada kepala, Waka Kurikulum, dan wali kelas TK B di TKIT Umar Bin Khathab kudus yang menjelaskan bahwa di lembaga tersebut dilakukan koordinasi oleh para pendidik dan kependidikan, saling terbuka membahas apa saja yang 
dianggapnya kesulitan, ataupun untuk memperkuat koordinasi antar stakeholder, yang mana dijelaskan bahwa setiap seminggu sekali adalah koordinasi dan rapat antar pendidik, setiap sebulan sekali rapat koordinasi antar wali anak didik, pendidik, dan kependidikan.

Merubah dari pengendalian menjadi pemberdayaan. Karyawan tidak mau kalau secara terus menerus dimonitor. Mereka ingin selalu dilibatkan, diajak berdiskusi, dan berpendapat. Mereka juga harus diserahi tanggung jawab yang sesuai serta mendapatkan kesempatan untuk berkembang dan mendapat penghargaan atas prestasi yang diraih. Sebagaimana yang diperoleh data hasil wawancara peneliti kepada kepala, Waka Kurikulum, dan wali kelas TK B di TKIT Umar Bin Khathab kudus yang menjelaskna bahwa di lembaga tersebut selalu memberikan kepercayaan pada semua pendidik ataupun tenaga kependidikan, sebagaimana dijelaskan dalam wawancara bahwa, setiap bagian ada koordinator masing-masing, baik dalam koordinator kurikulum, muatan lokal, pembinanan, ataupun jika ada ketidakharmonisan antar pendidik.

Merubah dari fokus internal dan fokus eksternal, fokus internal adalah perhatian perusahaan atau organisasi pada kemampuan yang dimiliki saja, sehingga proses produksi dilaksanakan berdasarkan kemampuan tanpa memperhatikan permintaan pelanggan (push system) sedangkan TQM menganggap bahwa cara berproduksi seperti ini adalah pemborosan. $T Q M$ lebih memfokuskan pada kebutuhan dan harapan pelanggan (eksternal fokus) sehingga melaksanakan proses produksi tarik (pull system).Sebagaimana yang diperoleh data hasil wawancara peneliti kepada kepala, Waka Kurikulum, dan wali kelas TK B di TKIT Umar Bin Khathab kudus yang menjelaskan bahwa di lembaga tersebut lebih mengutamakan kebutuhan anak didik yang memang sesuai keinginan para wali anak didik, yang mana mereka menginginkan anaknya dari pagi sampai siang ada yang melindungi ketika orang tua sedang bekerja, bukan hanya itu, para wali anak didik menginginkan supaya anak-anak mereka mendapatkan pendidikan yang benar-benar berkualitas, baik itu pendidikan keIslaman maupun pendidikan akademik. 
Merubah dari biaya dan penjualan menjadi kesesuaian terhadap mutu. Semula, perusahaan atau organisasi hanya memperhatikan masalah biaya dan waktu produksi. Namun kondisi tersebut kemudian berubah menjadi mutu produk yang menjadi orientasinya. Mutu produk yang dimaksud di sini adalah dengan memperhatikan kebutuhan dan harapan pelanggan. Barang atau jasa dikatakan bermutu bila mampu mengurangi biaya (cost reduction), menghilangkan pemborosan (eliminating waste), menyampaikan secara tepat waktu (faster delivery), dan menjual dengan harga terjangkau (lower price). Apabila hal tersebut tercapai, maka profit meningkat.

Merubah dari stabilitas menjadi perubahan dan perbaikan secara terus menerus. Organisasi yang mau berubah dan mau secara terus menerus mengadakan perbaikan itulah yang akan berhasil dengan baik. Dalam kondisi yang serba stabil, orang tidak akan pernah mau belajar. Sementara dalam organisasi yang menggunakan filosofi $T Q M$ dituntut untuk selalu belajar atau berubah, memperbaiki atau meningkatkan kemampuannya, karena prinsip TQM yang continuous quality improvement.

Merubah dari hubungan yang sifatnya persaingan menjadi hubungan kerjasama. Dalam organisasi yang menggunakan konsep TQM semua pihak yang berhubungan baik secara langsung maupun tidak langsung dengan organisasi tersebut (pemasok, pelanggan, pesaing, dan lain-lain) adalah teman atau saudara. Hal ini menuntut adanya kerjasama yang kuat dan saling membantu. Hubungan erat dan kerjasama yang baik dengan pelanggan akan membuat mereka terbuka untuk memberikan kritik dan saran untuk peningkatan produk dan jasa yang dihasilkan perusahaan.

Usaha untuk melibatkan karyawan membawa dua manfaat utama. Pertama, meningkatkan kemungkinan dihasilkannya keputusan yang baik, rencana yang baik, atau perbaikan yang lebih efektif karena juga mencakup pandangan dan pemikiran dari pihak-pihak yang langsung berhubungan dengan situasi kerja. Kedua, meningkatkan rasa memiliki dan tanggung jawab atas keputusan dengan melibatkan orang-orang yang harus melaksanakannya.Hal ini dapat dilakukan dengan melakukan perbaikan secara berkelanjutan terhadap mutu sumber daya manusia, proses, dan 
fasilitas fisik melalui suatu sistem penjaminan mutu yang memadai. Lembaga pendidikan perlu mengendalikan mutu kegiatan yang diselenggarakan pada setiap tahapan dalam prosesnya mencakup input, proses, output, dan kepuasan stakeholders.

Prinsip-prinsip Total Quality Management atau kualitas Mutu Terpadu, yang biasa disebut Manajemen Mutu Terpadu Pendidikan, diantara Prinsipprinsipnya antara lain:

a. Kepuasan Pelanggan. Dalam Manajemen Mutu Terpadu Pendidikan, konsep mengenai mutu dan pelanggan diperluas. Mutu tidak hanya bermakna kesesuaian dengan spesifikasi-spesifikasi tertentu, tetapi mutu tersebut ditentukan oleh pelanggan. Pendidikan adalah pelayanan jasa, maka sekolah harus memberikan pelayanan jasa sebaik-baiknya kepada pelanggannya. Pelanggan sekolah meliputi pelanggan internal dan pelanggan eksternal sekolah. Pelanggan eksternal sekolah adalah orang tua peserta didik, pemerintah, dan masyarakat termasuk komite sekolah.Pelanggan internal sekolah adalah peserta didik, guru, dan staf tata usaha. Oleh karena itu aktivitasnya harus dikoordinasikan untuk memuaskan para pelanggan. Semakin tinggi nilai yang diberikan maka semakin besar pula kepuasan pelanggan. Esensi Manajemen Mutu Terpadu Pendidikan adalah pelanggan dalam manajemen tersebut harus dipuaskan.

b. Respek Terhadap Setiap Orang. Sekolah yang bermutu kelas dunia, setiap orang di sekolah di pandang memiliki potensi. Orang yang ada di organisasi dipandang sebagai sumber daya organisasi yang paling bernilai dan dipandang sebagai asset organisasi. Oleh karena itu, setiap orang diperlakukan dengan baik dan diberikan kesempatan untuk berprestasi, berkarier, dan berpartisipasi dalam pengambilan keputusan.

c. Manajemen Berdasarkan Fakta. Setiap keputusan selalu didasarkan pada fakta, bukan pada perasaan (feeling) atau ingatan semata. Ada dua konsep yang berkaitan dengan hal ini yakni prioritatas.

d. Perbaikan Terus-Menerus. Supaya dapat sukses setiap sekolah perlu melakukan proses sistematis dalam melaksanakan perbaikan 
berkesinambungan. Konsep yang berlaku adalah siklus PDCA, yang terdiri langkah Perencanaan, melaksanakan rencana, memeriksa hasil pelaksanaan rencana, dan melakukan tindakan korektif terhadap hasil yang diperoleh.Jadi suatu institusi pendidikan disebut bermutu apabila antara pelanggan internal dan eksternal telah terjalin kupuasan atas jasa yang diberikan. Maka dari itu, untuk memposisikan institusi pendidikan sebagai industri jasa, harus memenuhi standar mutu. Institusi dapat disebut bermutu dalam konsep TQM, harus memenuhi spesifikasi yang telah ditetapkan.TQM menuntut pemberlakuan diseluruh organisasi, baik vertikal maupun horizontal (Husaini Usman, 2009 : 572-573).

Konsep Total Quality Management dalam Pendidikan di Taman Kanak-Kanak Islam Terpadu Umar Bin Khathab Kudus dalam Proses penerapan sistemnya memerlukan perencanaan yang jelas dan matang. Hal ini sesuai bahwa dalam mendirikan lembaga tersebut diberikan pondasi Visi, Misi dan Tujuan dari lembaga. Diantaranya tujuan lembaga tersebut adalah membantu perkembangan fisik, psikis, sosial serta intelektual secara optimal selaras dengan nilai-nilai Islam untuk menuju jenjang pendidikan dasar, serta menjadi lembaga pendidikan pra-sekolah rujukan di kabupaten Kudus (Data Dokumen Kurikulum TKIT Umar Bin Khathab Tahun 2017, Yayasan Pendidikan Al Fath TKIT Umar Bin Khathab Jl. Kudus-Jepara No. 82 Purwosari dan J1. Pangeran Puger No. 33 Kudus).Selain itu konsep penerapan Total Quality Management atau penerapan kualitas mutu terpadu di TKIT Umar Bin Khathab Kudus diawali dengan analisis internal dan eksternal yaitu melakukan evaluasi program-program sekolah yang dilakukan setiap awal dan akhir semester, menjelang awal dan akhir pergantian tema, serta menjelang awal dan akhir tahun pelajaran, seperti yang dijelaskan oleh Ibu Waka Kurikulum TKIT Umar Bin Khathab Kudus. Sehingga memang dalam perencanaan lembaga pendidikan perlu adanya persiapan jangka panjang untuk keperluan semester yang akan datang.

Berdasarkan observasi terhadap dokumen TKIT yang dilakukan peneliti, TKIT Umar Bin Khathab Kudus menyusun rencana kerja, baik rencana kerja jangka pendek, rencana kerja jangka menengah, dan rencana 
kerja jangka panjang, sebagai pemenuhan standar pengelolaan pendidikan. Sebagai bukti otentik TKIT mengarsipkan dokumen mengenai rencana kerja jangka pendek, rencana kerja jangka menengah, dan rencana kerja jangka panjang tersebut kedalam Dokumen Rencana Pengembangan TKIT Umar Bin Khathab Kudus dan mengacu pada beberapa tahapan yang dimusyawarahkan dari pihak yayasan sosial pendidikan Al Fath bersama para jajarannya dan pihak-pihak terkait Jaringan Sekolah Islam Terpadu (JSIT) Kabupaten Kudus, yang mana sesuai dengan karakteristik khusus $T Q M$ antara lain yakni Partisipasi aktif dari semua pihak, baik pimpinan maupun karyawan. Dalam prinsip implementasi Total Quality Management, partisipasi aktif dalam semua pihak memang sangat diperlukan sebagai power dan kemudahan serta keefektifan program yang telah ditentukan.

Kegiatan apapun yang berkaitan dengan program TKIT Umar Bin Khathab sangat membutuhkan keikutsertaan dari pihak SDM sekolah.Konsep terpadu yakni perpaduan antara konsep pendidikan secara umum dari kedinasan dengan konsep pendidikan dari JSIT, intinya perpaduan antara konsep dinas dan pembelajaran agama dijadikan satu. Pihak yang terlibat TKIT Umar Bin Khathab tidak hanya dari pihak intern seperti guru dan karyawan saja, namun juga pihak wali murid diajak untuk ikut berperan aktif untuk peduli perkembangan anak-anaknya dan mengetahui perkembangan lembaga pendidikan TKIT Umar Bin Khathab. TKIT Umar Bin Khathab benar-benar semua pihak dianjurkan untuk ikut berperan aktif. Bukan hanya sekedar program-program saja, namun benarbenar harus dilakukan. Dimana salah satu program keharusan dari TKIT Umar adalah mengharuskan semua pihak SDM nya untuk setor hafalan Al Qur'an setiap sepekan sekali, mengingat program tahfidz adalah program unggulan di TKIT Umar Bin Khathab Kudus.

2. Analisis Tentang Implementasi Total Quality Management Pendidikan Dalam Pengembangan Kurikulum Dengan Pendekatan Uswah Hasanah Di TKIT Umar Bin Khathab Kudus.

Prinsip keterpaduan ini menjadikan pengetahuan agama, pengetahuan sosial, pengetahuan alam (sains), dan pengetahuan lainnya pada dasarnya adalah berasal dari Tuhan. Maka pendidikan yang islami adalah pendidikan 


\section{Himmatul}

yang mendasarkan pada pandangan kesatuan, dan mengarah pada terwujudnya keadaan masyarakat (Abudin Nata, 2007 : 186).

Optimalisasi pencapaian tujuan-tujuan diatas memerlukan pendekatan dan pengelolaan tertentu dalam mengembangkan kurikulumnya, sehingga kualitas lembaga pendidikan dapat terus ditingkatkan. Total Quality Manajemen sebagai manajemen kualitas perlu diimplementasikan dalam pengembangan kurikulum lembaga pendidikan. Untuk mewujudkan total quality dalam lembaga pendidikan, implementasi pilar TQM dalam pengembangan kurikulum perlu menjadi pertimbangan dan perhatian serius. Memuaskan harapan pelanggan berarti mengantisipasi kebutuhan pelanggan pada masa datang. Sekolah perlu mengembangkan fokus kualitas, setiap orang dalam sistem sekolah mesti mengakui bahwa setiap output lembaga pendidikan adalah kostumer. Kurikulum yang disusun harus dapat mengakomodir perkembangan masyarakat dan kemajuan ilmu pengetahuan dan teknologi. Pengembangan kurikulum lembaga pendidikan dengan fokus pada kebutuhan masyarakat (pelanggan) diharapkan dapat menghasilkan lulusan yang dibekali pengetahuan keahlian dalam agama sekaligus keduniaanya. Oleh Karena itu, lembaga pendidikan akan dikatakan baik dan efektif jika lembaga pendidikan itu mencapai tujuannya dengan melahirkan lulusan yang berkualitas sesuai dengan harapan pelanggan atau masyarakat. Harapan masyarakat terhadap kurikulum lembaga pendidikan adalah lahirnya kurikulum yang dapat memberi kompetensi peserta didik pada bidang keilmuan secara umum dan juga penguasaan bidang keagamaan.

Manajemen pendidikan mutu terpadu berlandaskan pada kepuasan pelanggan sebagai sasran utama, baik pelanggan dalam (InternalCustomer) maupun pelanggan luar (ExternalCustomer). Dalam dunia pendidikan, yang termasuk pelanggan dalam adalah penglola institusi pendidikan, guru, staff, dan penyelenggara institusi. Sedangkan pelanggan luar adalah masyarakat, pemerintah dan dunia industri. Jadi suatu institusi pendidikan disebut bermutu apabila antara pelanggan internal dan eksternal telah terjalin kupuasan atas jasa yang diberikan.Maka dari itu, untuk memposisikan institusi pendidikan sebagai industri jasa, harus memenuhi standar mutu. 
Institusi dapat disebut bermutu dalam konsep TQM, harus memenuhi spesifikasi yang telah ditetapkan.

Jika pihak lembaga pendidikan mampu memberikan alternatif yang dapat diterima dengan senang hati bagi para wali murid, maka memang benar itu adalah bagian dari kepuasan pelanggan atau pengguna. Konsep kurikulum terpadu yang digunakan oleh TKIT Umar Bin Khathab Kudus, menjadi salah satu alternatif yang mampu menjawab kerisauan para orang tua anak didik. Bukan hanya kepuasan pengguna atau pelanggan dari pihak wali anak didik dan pihak-pihak terkait se kabupaten Kudus, tetapi juga pihak-pihak terakait pendidikan lanjutan yang sejalan dengan program unggulan yakni tahfidz.

Keterlibatan total dari pihak guru maupun karyawan TKIT Umar Bin Khathab sangat diutamakan, sehingga kunci utama adalah memberikan keteladanan bagi semua anak didik.Cara pengukuran kefektifan hasil belajar di TKIT Umar Bin Khathab salah satunya adalah dengan pengukuran di tingkat kompetisi Kabupaten, ini adalah cara pengukuran hasil belajar anak yang mampu memberikan pengalaman nyata bagi anak didik, apakah dia mampu menjadi terbaik ataukah hanya menjadi variasi dalam kompetisi, meskipun lomba ini bukan untuk menang atau kalah, yang terpenting adalah anak didik mampu dan berani tampil sesuai kemampuan maksimalnya.

Berdasarkan analisis peneliti, pembelajaran yang efektif memerlukan antara lain; Manajemen pendidikan yakni proses belajar mengajar harus dikelola dengan baik, adanya kurikulum untuk menunjang keberhasilan proses pembelajaran, profesionalisme guru, buku panduan dan sarana pendidikan, ingkungan sekolah, partisipasi masyarakat. Berdasarkan beberapa hal tersebut dapat disimpulkan bahwa ujung tombak sebuah lembaga pendidikan adalah manajemen yang baik terhadap lembaga dan kurikulum, kemudian yang menjadi kunci utama adalah pendidik dan tenaga kependidikannya harus mampu menjadi teladan untuk semua anak didik.

Perbaikan secara berkala di TKIT Umar Bin Khathab sangat diutamakan untuk perbaikan dan evaluasi program ke TK-an dan muatan lokal ke Islamannya. Ini sangat diperlukan karena untuk memastikan ke update an program. Usaha untuk perbaikan secara berkala sangat 
diutamakan untuk perbaikan dan evaluasi program ke TK-an. Ini sangat diperlukan kaena untuk memastikan ke update an program. Usaha untuk perbaikan secara berkala sangat diutamakan untuk perbaikan dan evaluasi program untuk semua agenda lembaga pendidikan TKIT Umar bin Khathab Kudus. Baik untuk guru maupun karyawan. Perbaikan berkelanjutan itu sangat penting karena seorang guru dan karyawan untuk menjadi teladan perlu adanya perbaikan dan kebersamaan.

Perbaikan berkelanjutan yakni dengan cara mengadakan study banding menjadikan salah satu cara untuk memperbaiki sistem dan program yang diterapkan selama berjalan 2 tahun, adakah yang perlu di evaluasi dan diperbaiki untuk kualitas lembaga dan program-program didalamnya. Jadi, selain pendidik intern sebagai uswah atau teladan bagi anak didik. Para pendidik juga mengambil lembaga lain atau tokoh inspirator lain sebagai teladan untuk memperbaiki lembaganya sendiri. Sehingga lembaga TKIT Umar pernah menjadi lembaga pendidikan TK terbaik se kabupaten Kudus, salah satunya telah mampu menerapkan kurikulum 2013 secara utuh, berkualitas dan efisien, dan menjadi rujukan atau teladan bagi lembaga anak usia dini kabupaten Kudus (berdasarkan hasil wawancara kepala TKIT Umar Bin Khathab Kudus).

Penulis dapat menarik kesimpulan bahwa Implementasi Total Quality Management pendidikandalam pengembangan kurikulum dengan pendekatan Uswah Hasanah di TKIT Umar Bin Khathab Kudus, jika dikategorikan dalam komponen TQM maka hasil tersebut masuk kedalam beberapa komponen yakni:fokus pada kepuasan pelanggan, keterlibatan total, pengukuran hasil, komitmen, dan perbaikan berkelanjutan (TerusMenerus).

3. Analisis Tentang Peranan Sistem Total Quality Management Pendidikan Dalam Meningkatkan Kinerja Organisasi Dengan Pendekatan Uswah Hasanah Di TKIT Umar Bin Khathab Kudus

a. Organisasi

Organisasi berasal dari bahasa Latin, Organum yang berarti alat, bagian atau badan. Organisasi menurut Sutarto mendefinisikan 
organisasi sebagai kumpulan orang, proses pembagian kerja, dan sistem kerja dan sistem kerjasama atau sistem sosial. Intinya bahwa organisasi merupakan proses kerja sama dua orang atau lebih untuk mencapai tujuan organisasi secara efektif dan efisien. Definisi ini bersifat umum dan berlaku bagi semua organisasi termasuk organisasi pendidikan.

\section{b. Kinerja Karyawan}

Ada perbedaan pengukuran kinerja secara tradisional dan kontemporer.Pengukuran kinerja tradisional dilakukan dengan membandingkan kinerja aktual dengan kinerja yang dianggarkan atau biaya standar sesuai dengan karakteristik pertanggung jawabannya, sedangkan pengukuran kinerja kontemporer menggunakan aktivitas sebagai pondasinya. Ukuran kinerja dirancang untuk menilai seberapa baik aktivitas dilakukan dan dapat mengidentifikasi apakah telah dilakukan perbaikan yang berkesinambungan.

Kinerja perusahaan dapat diukur dalam 2 (dua) dimensi kinerja yaitu kinerja operasional dan kinerja organisasi. Kinerja operasional mencerminkan kinerja operasi internal perusahaan dalam hal biaya dan pengurangan pemborosan, meningkatkan kualitas produk, pengembangan produk baru, memperbaiki kinerja pengiriman, dan peningkatan produktivitas.Indikator dan variabel tersebut dianggap sebagai faktor utama karena mereka mengikuti langsung dari tindakan yang diambil dalam kegiatan operasi perusahaan. Sedangkan kinerja organisasi diukur dengan ukuran finansial seperti pertumbuhan pendapatan, laba bersih, rasio laba dengan pendapatan dan laba atas asset, dan non-ukuran finansial seperti investasi dan kapasitas perusahaan untuk mengembangkan profil kompetitif.

Untuk mencapai tujuan kinerja karyawan maka dapat dinilai dari tiga hal, meliputi; penilaian harus mempunyai hubungan dengan pekerjaan, adanya standar pelaksanaan kerja, praktis (mudah dipahami atau dimengerti karyawan atau penilai)". Indikator dalam kinerja adalah: Overall quality adalah persepsi karyawan terhadap kualitas hasil kerja secara keseluruhan. Reliability adalah persepsi karyawan terhadap kualitas kerja yang telah diperoleh karyawan tersebut akurat/sesuai 
dengan informasi yang ada dan dapat dipercaya. Employee quality adalah persepsi terhadap kualitas tenaga kerja menyangkut kesesuaian kemampuan dan kapabilitas setelah melaksanakan pekerjaannya.

Sebuah organisasi harus dilandasi dengan rasa komitmen dan tanggung jawab antara sesama anggota organisasi untuk kemajuan dan tercapainya tujuan organisasi (lembaga pendidikan). Berikut ini merupakan lima kunci komitmen diantaranya yakni:Komitmen terhadap organisasi, Komitmen terhadap diri sendiri, Komitmen terhadap konsumen, Komitmen terhadap orang lain dan komitmen terhadap Tugas (Husaini Usman : 298-300).Manajemen mutu terpadu yang diterapkan pada suatu lembaga pendidikan sedikit banyak pasti harus memberikan peranan penting bagi lembaga pendidikan tersebut. Peranan sistem Total Quality Management pendidikan dalam Meningkatkan Kinerja Organisasi dengan Pendekatan Uswah Hasanah di TKIT Umar Bin Khathab Kudus. Berikut ini merupakan KomponenKomponen Total Quality Manajemen adalah sebagai berikut;Fokus pada kepuasan pelanggan, Obsesi terhadap mutu, Pendekatan Ilmiah, Komitmen jangka panjang, Kerjasama Tim (Teamwork), Perbaikan sistem secara terus menerus, Pendidikan dan pelatihan, Kebebasan yang terkendali, Kesatuan tujuan, Adanya keterlibatan dan pemberdayaan guru dan staf tata usaha.

Berdasarkan hasil penelitian lapangan dan analisis tersebut diatas, maka penulis dapat menarik kesimpulan bahwa Peranan Total Quality Management pendidikan dalam Meningkatkan Kinerja Organisasi dengan pendekatan Uswah Hasanah di TKIT Umar Bin Khathab Kudus, jika dikategorikan dalam komponen TQM maka hasil tersebut masuk kedalam beberapa komponen yakni sebagai berikut; Obsesi terhadap mutu, Komponen pertama penerapan Total Quality Management pendidikan yang berkaitan dengan peranan TQM dalam meningkatkan kinerja organisasi dengan pendekatan uswah hasanah di TKIT Umar Bin Khathab Kudus, yakni obsesi terhadap mutu. Bahwa semangat untuk perbaikan dimasa mendatang atau obsesi terhadap mutu semua pihak guru ataupun karyawan di TKIT Umar Bin Khathab sangat maksimal 
untuk program kurikulum 2013 sehingga dapat diterapkan di TKIT Umar Bin Khathab Kudus. TKIT Umar Bin Khathab semangat usaha mengikuti pelatihan di provinsi yang dilakukannya bersama semua pihak guru dan karyawannya yang memang membuktikan kebenaran bahwa semua pihak pendidik dan tenaga kependidikan di TKIT Umar Bin Khathab sangat terobsesi dengan mutu atau kualitas pendidikan anak usia TK untuk memastikan dan meningkatkan kualitas lembaga pendidikan TKIT Umar Bin Khathab Kudus.

Pendekatan Ilmiah, Pendekatan ilmiah yang dilakukan dalam program Terpadu TKIT Umar Bin Khathab diantaranya bahwa di lembaga pendidikan TKIT Umar Bin Khathab Kudus meskipun di tingkat pendidikan TK namun semua pihak guru maupun tenaga kependidikannya tidak ketinggalan untuk belajar dengan mengadakan bedah buku bersama pada tenaga pendidik dan kependidikan. Kerjasama Tim (Teamwork), Kerjasama Tim yang dilakukan daam program Terpadu TKIT Umar Bin Khathab sangat jelas terlihat dalam setiap program tentu ada tim, itulah membuktikan bahwa kerja tim di TKIT Umar Bin Khathab sangat dibutuhkan untuk menjadikan semua program di lembaga semakin efektif dan efisien.

Pendidikan Dan Pelatihan. Pendidikan dan pelatihan yang dilakukan daam program Terpadu TKIT Umar Bin Khathab diantaranya ada kegiatan-kegiatan pelatihan dari Dinas, workshop, angkat permasalahan dan memanggil narasumber untuk memberikan pengarahan atau pembinaan dan pelatihan. Bahwa seluruh tenaga pendidik dan kependidikan di TKIT Umar Bin Khathab selalu memberikan dan memenuhi kebutuahan pendidikan dan pelatihan untuk meningkatkan kualitas gabi para pendidik dan pegawainya.

Kebebasan Yang Terkendali, hal ini sesuai dengan pernyataan kurikulum 2013 tidak ada ketentuan paten, semua sesuai otoritas lembaga. Intinya, kami sebagai lembaga di bawah naungan Dinas, juga kami terprogram sesuai JSIT sabagai program unggulan kami. Berdasarkan penjelasan diatas membuktikan bahwa penerapan kurikulum 2013 diterapkan di TKIT Umar Bin Khathab dengan 
semaksimal mungkin dan sesuai situasi kondisi dan kebutuhan peserta didik. Kesatuan Tujuan, Jadi tidak hanya cukup yang penting sudah S1 PAUD atau sudah membuat RPP, mengajar, lalu pulang, Tidak. Semua guru mempunyai tugas dan tanggung jawab. Karna misinya dakwah menyampaikan kebaikan atau kebenaran melalui anak didik. Manajemen terpadu yang dilakukan oleh TKIT Umar Bin Khathab selalu mengarahkan dan mengajak kembali tujuan yang sama dengan mengembalikan power kebersamaan dengan tanggung jawab dan amanat yang bersama-sama ditanggung untuk kemajuan, kualitas dan kemanfaatan lembaga. Kesatuan tujuan dalam sebuah organisasi itu sangat penting dari setiap elemen, karena dimana kesatuan tujuan tercapai maka akan memudahkan persatuan itu menuju tujuan utama yang ingin dicapai bersama.

\section{Simpulan}

Konsep Total Quality Management dalam Pendidikan di Taman KanakKanak Islam Terpadu Umar Bin Khathab Kudus dalam Proses penerapan sistemnya memerlukan perencanaan yang jelas dan matang. Hal ini sesuai bahwa dalam mendirikan lembaga tersebut diberikan pondasi Visi, Misi dan Tujuan dari lembaga. Selain itu konsep penerapan Total Quality Management atau penerapan kualitas mutu terpadu di TKIT Umar Bin Khathab Kudus diawali dengan analisis internal dan eksternal yaitu melakukan evaluasi program-program sekolah yang dilakukan setiap awal dan akhir semester, menjelang awal dan akhir pergantian tema, serta menjelang awal dan akhir tahun pelajaran. Partisipasi aktif dari semua pihak, baik pimpinan maupun karyawan. Sosialisasi atau pelatihan, misalnya ada workshop yang harus diikuti semua tenaga pendidik dan kependidikan TKIT Umar. Konsep terpadu yang digunakan dari sisi aspek agama-moralnya lebih ditambah dengan muatan pendidikan al Qur'an atau Taman Pendidikan al Qur'an (TPQ) atau Madrasah, kemudian dipadukan dengan konsep Dinas, sehingga menjadi pendidikan terpadu. Sehingga dari pihak orang tua anak, diantara beberapa atau kebanyakan orang tua anak dengan keterbatasan waktu mereka yang tidak sempat untuk menyekolahkan anaknya di sore hari di Taman Pendidikan al Qur'an, maka di sistem manajemen terpadu ini sudah merangkumnya menjadi satu, sehingga ini bisa menjadi alternatif bagi para 


\section{Himmatul}

orang tua yang sehari-harinya sibuk waktunya habis untuk kerja dari pagi sampai sekitar sore. Program yang diutamakan untuk penerapan sistem Total Quality Management selanjutnya adalah menanamkan budaya kerja tim. Dalam membuat program kami bentuk Tim. Menanamkan budaya problem solving melalui konsep PDCA (Plan-Do-Check-Action). Konsep penerapan manajemen mutu terpadu selanjutnya yakni Menanamkan budaya problem solving,dan perbaikan berkelanjutan. Komponen-Komponen Total Quality Manajemen adalah sebagai berikut; Fokus pada Pelanggan, Keterlibatan Total, Pengukuran, Komitmen, Perbaikan Berkelanjutan. Peranan Total Quality Management pendidikan dalam Meningkatkan Kinerja Organisasi dengan pendekatan Uswah Hasanah di TK IT Umar Bin Khathab Kudus. Diantaranya yakni: Obsesi terhadap mutu, Pendekatan Ilmiah, Kerjasama Tim (Teamwork), Pendidikan Dan Pelatihan, Kebebasan yang Terkendali, Kesatuan Tujuan.

\section{Daftar Pustaka}

Data Dokumen Kurikulum TKIT Umar Bin Khathab Tahun. 2017. Yayasan Pendidikan Al Fath TKIT Umar Bin Khathab Jl. Kudus-Jepara No. 82 Purwosari dan Jl. Pangeran Puger No. 33 Kudus.

Direktorat Pendidikan Anak Usia Dini, Direktorat Jenderal Penddikan Non Formal dan Informal Kementerian Pendidikan Nasional. 2010. Pedoman Teknis Penyelenggaraan Kelompok Bermain.

Kunandar. 2007. Guru Profesional, Raja Grafindo Persada, Jakarta.

Hasan, Maimunah. 2012. Pendidikan Anak Usia Dini, DIVA Press, Jogjakarta. 
Nata, Abudin. 2007. Manajemen Pendidikan, Mengatasi Kelemahan Pendidikan Islam di Indonesia, Kencana, Jakarta.

2007. Manajemen Pendidikan, Mengatasi Kelemahan Pendidikan Islam di Indonesia, Kencana, Jakarta.

Undang-undang No. 20 tahun 2003 tentang sistem pendidikan nasional pada bab IV pasal II ayat 2, diakses pada tanggal 27 Oktober 2017.

Undang-Undang Republik Indonesia Nomor 20 tahun 2003 tentang Sistem Pendidikan Nasional, Bab 1, Pasal 1.

Undang-Undang Republik Indonesia Nomor 20 tahun 2003, Pasal 1 ayat 14.

Usman, Husaini. 2009. Manajemen Teori, Praktik dan Riset Pendidikan Edisi 3, Bumi Aksara, Jakarta.

Veithzal Rivai dan Sylviana Murni. 2010. Education Management Analisis Teori dan Praktik, Rajawali Pers, Jakarta.

Wahab, Abdul Aziz. 2011. Anatomi Organisasi dan Kepemimpinan Pendidikan Telaah Terhadap Organisasi dan Pengelolaan Organisasi Pendidikan, Alfabeta, Bandung. 